\title{
Is Contributory Negligence of Deceased a Defense to a Wrongful Death Action?
}

\section{Paul Nourse*}

UNDOUBTEDLY, the mere posing of this question will be a shock to most members of the California Bar, for, insofar as my research discloses, no member of the Bar has ever suggested to the Supreme Court or any Appellate Court an answer in the negative. Both the Supreme and Appellate Courts, in all their decisions since the enactment of Section 377 of the Code of Civil Procedure in 1872, have without discussion of the question or any analyzation of the section, assumed that the answer was in the affirmative.

A study of the section, of the law of this state prior to its enactment, and of the basis for the defense of contributory negligence as established by the decisions of the Supreme and Appellate Courts and our statutes, has raised in the writer's mind a grave doubt that this defense is available in actions for wrongful death based on the section.

Prior to 1862, the wrongful act of one person resulting in the death of another did not give rise to a cause of action in this state. ${ }^{1}$

In 1862 the Legislature enacted a statute creatimg such a cause of action. ${ }^{2}$ This statute was in substance Lord Campbell's Act and, like that Act, expressly provided that the cause of action should only vest in the personal representative of the deceased, if the deceased, had he survived, could have maintained an action against the tortfeasor.

Under this statute it was necessary that the plaintiff prove, as a part of his case, not only the negligence of the defendant but that the deceased was free from negligence contributing in any degree to the injury which resulted in his death. ${ }^{3}$ Thus the statute created a cause of action in the personal representative only in those cases where the decedent did not, by his own negligence, contribute to the injury which resulted in his death.

In 1872 this statute was repealed by the enactment of the Code of Civil Procedure and particularly by the enactment of Section $377 .{ }^{4}$ In enacting Section 377 of the Code of Civil Procedure, the Legislature made two substantial changes in the statutory right of action granted. First, it gave the right of action to the heirs or to the personal representative of the deceased

*Judge, Los Angeles Superior Court.

1 Kramer v. Market Street R.R., 25 Cal. 434 (1864).

2 Cal. Stats. 1862, p. $44 \%$.

3 Gay v. Winter, 34 Cal. 153 (1867).

4 Cat. Code Civ. Proc. \& 18 
instead of to the personal representative only. Second, it deleted the proviso of the former statute whicl made the decedent's freedom from negligence a condition upon the cause of action created.

It is an established rule of statutory construction that when the Legislature, in enacting a statute which substitutes a new statute for a former one on the same subject, leaves out a substantive provision of the former statute, it discloses a clear intent that the matter omitted shall no longer be the law of the State. ${ }^{5}$ This rule of statutory construction has been specifically applied to changes in former statutes througl the adoption of the Codes. ${ }^{B}$

That the Legislature intended to substitute a new and different cause of action for wrongful death by the enactment of Section 377 of the Code of Civil Procedure is also indicated by the Code Commissioners in their note to the section in the first annotated Code of Civil Procedure, ${ }^{7}$ for there they say, "this section is intended as a substitute for 'an act requiring compensation for causing death by wrongful act, neglect or default.' Statutes of 1862, page 447."

The cause of action for wrongful death is purely statutory. The cause of action arises out of the death, and is entirely separate and distinct from any cause of action the decedent might have had. ${ }^{8}$

Upon the grounds that the cause of action for wrongful death is a new cause of action and separate and distinct from any cause of action that the deceased might have had, it has been uniformly held that the admissions of the decedent against his interests and which might tend to establisl his negligence, are not admissible against his heirs in an action brought under Section 377 of the Code of Civil Procedure. ${ }^{9}$ It seems anomalous to hold that the negligence of the decedent will defeat a cause of action for his death, and to hold that his own admissions may not be used as proof of his negligence.

The Legislature not having made the decedent's freedom from negligence a condition upon the cause of action which it created, the Courts are

E People v. Valentine, 28 Cal.2d 121, 142, 169 P.2d 1, 14 (1946) ; Estate of Todd, 17 Cal.2d 270, 274, 109 P.2d 913, 915 (1941).

8 Estate of Carragher, 181 Cal. 15, 183 Pac. 161 (1919).

7 CAc. Code Crver Proc., annotated by Creed Haymond and John C. Burch, California Code Commissioners. (HI. S. Crocker \& Co., Printers, 1872.)

8 Bond v. United Railroads of San Francisco, 159 Cal. 270, 113 Pac. 366 (1911) ; McLaughlin v. United Railroads of San Francisco, 169 Cal. 494, 147 Pac. 149 (1915) ; Clark v. Goodwin, 170 Cal. 52\%, 150 Pac. 357 (1915).

9 Hedge v. Williams, 131 Cal. 455, 63 Pac. 721 (1901) ; Marks v. Reissinger, 35 Cal. App. 44, 54, 169 Pac. 243, 248 (1917). 
without power to graft such conditions upon that cause of action. To do so would be to amend the statute by judicial decree. ${ }^{10}$

It may be argued that contributory negligence is a defense and therefore not properly a part of the statute, but let us see if it is a defense to this statutory cause of action. It has been said that Section 1714 of the Civil Code contains the statutory provisions for the defense of contributory negligence. ${ }^{11}$ So far as is pertinent here, Section 1714 provides:

Every one is responsible, not only for the result of his wilful acts but also for injuries occasioned to another by his want of ordinary care or skill ..., except so far as the latter has, wilfully or by want of ordinary care, brought the injuries upon himself .... (Italics ours.)

It is the italicized portion which is the foundation for the defense of contributory negligence.

It is clear that there is nothing in the section which allows one, who through negligence has injured another, to escape liability because someone other than the person injured by his negligence contributed to that injury. Yet this is what occurs when a defendant tortfeasor is permitted to plead the negligence of the decedent in an action for wrongful death founded upon Section 377 of the Code of Civil Procedure. It is the heirs of the decedent who have suffered pecuniary loss, who are the persons injured by the act of the tortfeasor. Certainly it cannot be said that the widow and minor children of a man killed by the negligence of another have, in the words of Section 1714, "wilfully or by want of ordinary care brought the injuries" upon themselves.

If we look to the decided cases for the basis for the defense of contributory negligence, or rather for the reasons that support it, we find that the reasons given have no application to an action for wrongful death. In Fujise v. Los Angeles Railway Company, Mr. Justice Taggart, speaking for the Court, said: ${ }^{12}$

In order that contributory negligence sliall prevent the recovery of damages for a personal injury, it must appear that the negligence is that of the injured person or of someone over whoin he exercised some control. The foundation of the doctrine is said to rest in the civil law maxim: 'Tle harm I bring upon myself I must bear myself.' (1 Beven on Negligence in Law, p. 149). The reason for the rule which so relieves the defendant from the payment of damages for his neghigence where the plaintiff has contributed

10 CaL. Const. Art. III, § 1; Allen v. Allen, 95 Cal. 184, 199, 30 Pac. 213, 216 (1892); Moore v. United States Fidelity and Guaranty Company, 122 Cal. App. 205, 211, 9 P.2d 562, 564 (1932); Chester v. Hall, 55 Cal. App. 611, 615, 204 Pac. 237, 240 (1921).

11 Milosevich vं. Pacific Electric Ry., 68 Cal. App. 662, 667, 230 Pac. 15, 17 (1924); Tucker v. United Railroads of San Francisco, 171 Cal. 702, 705, 154 Pac. 835, 837 (1916).

1212 Cal. App. 207, 211, 107 Pac. 317, 319 (1909). See also Needham v. San Francisco \& San Jose R.R., 37 Cal. 409, 419 (1869). 
to the injury by his own negligence, as it is applied in this state, is based upon an argument of convemence, to wit, the impossibility of successfully apportioning the damages between the parties, and not for the reason that the law relieves the defendant from responsibility merely because the injured party lias contributed to the result by lis own negligence or wrongful act.

In an action for wrongful death the plaintiffs have brought no injury upon themselves. The fact that the person, whose death gives rise to their cause of action, has by his own negligence, in some degree "however slight" contributed to his own injuries, is, under the language of the Court just quoted, or under the provisions of Section 1714 of the Civil Code, of no more moment than the contributing negligence of some third person.

Why, if one tortfeasor is liable for the entire damage caused to another as a result of the combined negligence of himself and another tortfeasor, should he escape all liability to the persons he has injured (the heirs), because a third person, the decedent, by his neghigence has contributed to their loss?

In 1907 the Califorma Legislature amended Section 1970 of the Civil Code and by that amendment created a cause of action for the benefit of certain heirs of an employee whose death resulted from the wrongful act of his employer. In the amending statute it is expressly provided "the rules and principles of law as to contributory negligence which apply to other cases shall apply to cases arising under this section ...."

It may be asserted that by the quoted language the Legislature intended to make the contributory negligence of the decedent a defense in all wrongful death cases. It is difficult to see how such construction can be placed upon the quoted language, but if it can be, still that would not affect the question here. In 1937 the Legislature repealed Section 1907 and in lieu thereof enacted Section 2803 of the Labor Code. Section 2803 of the Labor Code makes no reference to the contributory negligence of the decedent, again illustrating the intent of the Legislature that such neghigence should not be a condition upon or a defense to a cause of action for wrongful death.

It is submitted that the basis for the defense of contributory negligence is entirely lacking in an action for wrongful death. There can be no doubt that the right to plead contributory negligence of the deceased as a coinplete defense to an action for his wrongful death based upon Section 377 of the Code of Civil Procedure is stated by all the decisions dealing with the subject simce the enactment of Section 377. If, however, these decisions are in error, the Court should not hesitate to overrule them. No rights, contractual or otherwise, have become vested under them. ${ }^{13}$.

${ }^{13}$ Alferitz v. Borgwardt, 126 Cal. 201, 58 Pac. 460 (1899); Los Angeles v. Pomeroy, 124 Cal. 597, 611, 57 Pac. 585, 589 (1899); Carpenter, Stare Decisis and Law Reform, I So. CAJIT. L. REv. 53, 61-2 (1927). 
The writer expresses no opinion as to whether or not the contributory negligence of a decedent should be a defense in an action for his death under Section 377 of the Code of Civil Procedure. He only directs attention to the fact that under the present statutes it is not, and that it is for the Legislature, not the Courts, to remedy this evil, if evil it be. 